\title{
Potential of indigenous bacteria to remove cyanide with variations of contact time and temperature
}

\author{
Kezia Eunike $^{1}$, Astri Rinanti ${ }^{1}$, and Ratnaningsih Ratnaningsih ${ }^{1 *}$ \\ ${ }^{1}$ Universitas Trisakti, Environmental Engineering Department, Faculty of Landscape Architecture and Environmental Technology, \\ Jakarta, Indonesia
}

\begin{abstract}
The research on environmental biotechnology has been done in aims to study the ability of mixed culture indigenous bacteria to remove cyanide $\left(\mathrm{KCN}^{-}\right)$concentration which is determined by environment conditions of temperature and contact time. The research has been done using the artificial pollutants that contains $500 \mathrm{ppm}$ of $\mathrm{KCN}^{-}$which is exposed to the SMSS (Stone Mineral Salt solution) as a growth media for mixed culture bacteria TBS and CTS. The effect of different environment conditions including temperature and contact time were studied on cyanide removal. Gas Chromatography - Mass Spectrophotometer (GC - MS) method is used to analysed the concentrations of $\mathrm{KCN}^{-}$. Initial condition of research operation is determined to be $\mathrm{pH} 7$ and contact time of 48 hours. The removal of $500 \mathrm{ppm} \mathrm{KCN}^{-}$ increases to $71 \%$ at incubation temperature $35^{\circ} \mathrm{C}$ and contact time of 36 hours. This research showed that indigenous bacteria TB1 and CS2 can remove $500 \mathrm{ppm} \mathrm{KCN}^{-}$on all temperature variations between $\left({ }^{\circ} \mathrm{C}\right) 25$ to 45 and the highest removal occur when contact time is 36 hours.
\end{abstract}

\section{Introduction}

Cyanide contamination can occur in soil, river and ground flow. Cyanide is one of the chemicals used in gold mining and jewelry industry activities. The area around the gold mining industry is one area that is often exposed to heavy metal contamination and cyanide [1]. Cyanide contamination is common in areas around gold mining industry. The presence of cyanide in water and soil can harm the environment and human health [2]. Cyanide can affect negatively to human and animal health, to the point of causing death at a certain concentration. Therefore, required a processing to treat the contamination of the cyanide compound.

Cyanide is a toxic compound that can converted into less toxic substances. There are several methods that can treat waste water contaminated cyanide, either physical or chemical process. However, these methods generally require relatively high costs because they require further processing. Therefore, it takes alternative methods that are relatively cheaper and more environmentally friendly to treat wastewater and soil contaminated cyanide [3].

Waste water and soil contaminated by cyanide can processed by biological process. Bioremediation method is one of the biological process [4]. The process of biological treatment by utilizing microorganism can effectively reduce harmful chemicals that presence in environment [5]. Bioremediation is one of the biological process that can converting hazardous materials into simple non-toxic substances by utilizing the metabolic activity of microorganisms such as bacteria, fungi and plants. Some bacteria and fungi can decompose cyanide compounds by utilizing the enzymes produced from metabolic activity. Bioremediation process by utilizing bacteria considered safer, faster, cheaper and environmentally friendly to handle cyanide-containing wastes [6].

In the biological cyanide removal process, cyanide can be utilized as carbon and nitrogen source for the growth of microorganism under certain conditions. Some plants that isolated from cyanide contaminated tailing dam can remove cyanide such as Ipomoea sp., Limnocharis flava, Mucuna pruriens, Mikania cordata dan Cyperus sp.[1]. Pseudomonas sp., Klebsiella sp., Bacillus sp [7] and Rhodococcus sp. [8] are several bacteria that can remove cyanide. And there are also several types of fungi that can remove cyanide such as Fusarium oxysporum [9] dan Citrus sinensin [10].

In biological processing, the growth conditions of microorganisms can affect their performance to remove cyanide compound. The growth of microorganisms can be affected by changes in environmental conditions [11]. There are several environment conditions factor that affect microbial performances to remove cyanide, such as cyanide concentration, nutrient, temperature, $\mathrm{pH}$, and also contact time between cyanide and microbes and also presence of additional pollution [12].

In most previous studies, cyanide removal by utilizing different bacteria at different conditions. Most of the bacteria utilized are included in the class of mesophilic bacteria, which bacteria can growth optimally at temperatures between $25-30{ }^{\circ} \mathrm{C}$. Besides, contact time between bacteria and cyanide also affects

\footnotetext{
* Corresponding author: ratnaningsih $@$ trisakti.ac.id
} 
the cyanide removal depending on the type of bacteria utilized.

Based on the above description, this research aimed at studying the ability mixed culture TBS and CTS to remove cyanide in liquid media as preliminary research to treat waste water contaminated by cyanide. This study focuses on the effect of incubation temperature and contact time to obtain the highest cyanide removal.

\section{Research methodology}

\subsection{Research design}

This research of cyanide removal is carried out on liquid medium in batch culture. Mixed culture bacteria TBS and CTS cultured in the SMSS medium containing 500 ppm concentration of cyanide in Erlenmeyer flasks incubated at $150 \mathrm{rpm}$ in a shaker incubator. This study focuses on the effect of temperature and contact time on cyanide removal. These variables consisted on initial cyanide concentration $500 \mathrm{ppm}$ and $\mathrm{pH}$ of the medium which was adjusted to $\mathrm{pH} 7$; different incubation temperature $\left({ }^{\circ} \mathrm{C}\right)$ of $25,30,35,40$ and contact time (hours) was 12, 24, 36, 48. The research design can be seen in Fig. 1.

\begin{tabular}{|c|c|}
\hline \multicolumn{2}{|c|}{$\begin{array}{l}\text { Batch culture contain SMSS medium, TS1 and TS } \\
\text { and added } 500 \mathrm{ppm} \text { of } \mathrm{KCN}^{-} \text {. }\end{array}$} \\
\hline \multicolumn{2}{|r|}{ Independent Variable } \\
\hline I. & Temperature $\left({ }^{\circ} \mathrm{C}\right): 25,30,35,40$ \\
\hline \multicolumn{2}{|r|}{ Dependent Variable } \\
\hline $\begin{array}{l}\text { I. } \\
\text { II. } \\
\text { III. }\end{array}$ & $\begin{array}{l}\mathrm{pH}=7 \\
\text { Cyanide concentration }=500 \mathrm{ppm} \\
\text { Contact time (hours) }=48 \text { hours }\end{array}$ \\
\hline & 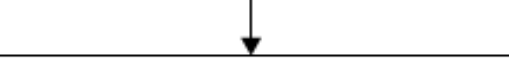 \\
\hline \multicolumn{2}{|r|}{ Independent Variable } \\
\hline I. & Contact Time (hours) : $12,24,36,48$ \\
\hline \multicolumn{2}{|r|}{ Dependent Variable } \\
\hline $\begin{array}{l}\text { I. } \\
\text { II. } \\
\text { III. }\end{array}$ & $\begin{array}{l}\mathrm{pH}=7 \\
\text { Cyanide concentration }=500 \mathrm{ppm} \\
\text { The best temperature from previous } \\
\text { experiment }\end{array}$ \\
\hline
\end{tabular}

Fig. 1. Research design.

\subsection{Analysis of bacterial growth}

The growth of bacteria was analyzed by using Total Plate Count method with Spread Plate Technique and colonies counted by using colony counter. The bacteria/ml can be calculated using the formula:

Bacteria $/ \mathrm{ml}=($ number of colonies $\mathrm{x}$ dilution factor $)$

\subsection{Analysis cyanide removal in liquid media}

Analysis Cyanide Removal in Liquid Media using GCMS (Gas Chromatography-Mass Spectrometer). Methods.

\section{Result and discussion}

\subsection{Susceptibility test}

The ability of bacterial growth to cyanide compound was tested by performing bacterial susceptibility test. Susceptibility test is a method that can be used to determine bacterial susceptibility to cyanide compound using paper discs. The susceptibility bacteria to cyanide compound can be seen from inhibition zone formed around paper discs with an incubation time of 48 hours.

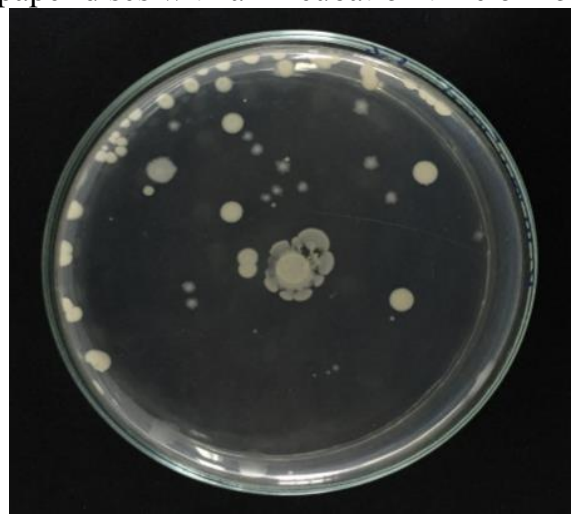

Fig. 2. Susceptibility bacteria test.

On bacterial susceptibility test if the diameter formed in the inhibition zone may be an indication of bacterial susceptibility to anti-bacterial substances [13]. The inhibitory power of microorganisms can be seen in the area around the paper discs overgrown by microorganisms. If inhibition zone is formed around a paper disc that contain $500 \mathrm{ppm}$ cyanide then this indicates that bacteria are sensitive to cyanide compound. Otherwise, if no inhibition zone is formed around the disk diffusion then the bacteria are resistant to cyanide, so that bacteria can grow in the presence of cyanide compound.

The test results show that no zone of inhibition is formed, so it can be seen that indigenous bacteria TBS and CTS are resistant to cyanide compound and able to grow in medium containing cyanide toxic compounds 500 ppm (Fig. 2.). Thus, based on the result the mixed culture of bacteria can be expected to remove cyanide pollutant because their ability growth on presence of cyanide compound.

\subsection{The effect of temperature variations on cyanide removal}

This research was conducted on controlled environment conditions in between $\mathrm{pH} \mathrm{7,500} \mathrm{ppm} \mathrm{concentration} \mathrm{of}$ cyanide compound and contact time for 48 hours. The results of cyanide removal at incubation temperature variation $\left({ }^{\circ} \mathrm{C}\right) 25,30,35,40$ can be seen in Fig. 3. The 
highest percentage of cyanide removal on incubation temperature variations will be used in the following experiments.

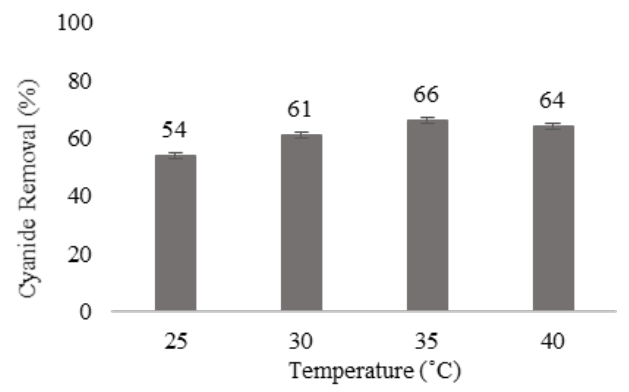

Fig. 3. Cyanide removal on incubation temperature variations.

Based on the results in Fig. 3. all variations in temperature indicate a cyanide removal above $50 \%$. The highest cyanide removal percentage occurred at $35^{\circ} \mathrm{C}$ od incubation temperature, although this cyanide removal did not differ significantly with cyanide removal percentage occurred at $40^{\circ} \mathrm{C}$ amount $64 \%$. The lowest cyanide removal occurred at $30^{\circ} \mathrm{C}$ amount $61 \%$. Thus, it appears that temperature has an effect on the cyanide removal process. Cyanide removal is higher at temperatures above $30^{\circ} \mathrm{C}$ but cyanide removal does not increase when the temperature is increased from $35^{\circ} \mathrm{C}$ to $40^{\circ} \mathrm{C}$.

Research conducted by [14] showed that the highest removal cyanide was occur at $25^{\circ} \mathrm{C}$ amount $65 \%$ by utilizing Halomonas sp. bacteria. In this research can be known that mixed culture bacteria able to remove cyanide up to $66 \%$ at maximum temperature $35^{\circ} \mathrm{C}$. Each bacterium has specific characteristics that affect its activity to remove cyanide. In this research cyanide removal was best at $35^{\circ} \mathrm{C}$ and this temperature will be applied in the following experiments the effect of contact time on cyanide removal.

\subsection{The effect of contact time on cyanide removal}

This research was conducted on controlled environment condition between $\mathrm{pH} \mathrm{7,500} \mathrm{ppm} \mathrm{concentration} \mathrm{of}$ cyanide and incubation temperature used $35^{\circ} \mathrm{C}$ from the previous experiment, with variations of contact time (hours) 12,24,36,48. The results of cyanide removal at contact time variations can be seen in Fig. 4.

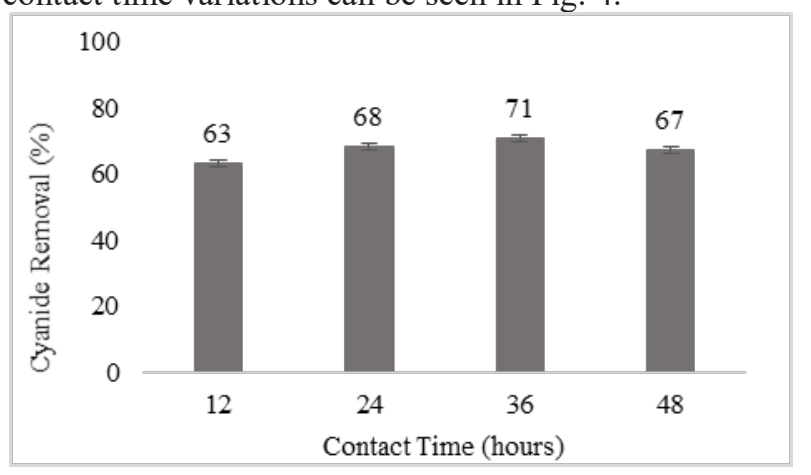

Fig. 4. Cyanide removal on contact time variations.
Fig. 4. shows the result of cyanide removal at contact time variation in the time span 12-48 hours ranging from $60 \%-75 \%$. The highest cyanide removal percentage of $71 \%$ occurred at 36 hours of contact time. Cyanide removal percentage at contact time of 24 hours and 48 hours is not much different from cyanide removal at 36 hours of contact time.

Bacteria require contact time for 120 hours to remove cyanide up to $76 \%$ [14]. In this study the maximum required time is for 36 hours or nearly three times faster than compared to the study [14]. This may occur because the bacteria utilized are different and there is synergism between the mixed culture bacteria that utilized in this study. The interaction between the mixed culture bacteria resulted in shorter contact time to remove the cyanide compound. The mixed culture of the bacterial was able to remove cyanide with contact time for 96 hours, whereas individual cultures were able to remove cyanide at the same percentage with contact time for 144 hours [15]

\section{Conclusions}

Mixed culture bacteria TBS and CTS can grow with cyanide presence in liquid medium that can be proven with no inhibition zone formed around the paper disc. The highest percentage of cyanide removal was $65 \%$ at $35{ }^{\circ} \mathrm{C}$ under environment condition, while the highest percentage of the cyanide removal on environmental conditions variation in contact time was $71 \%$ at 36 hours. Thus, it can be concluded that mixed culture bacteria TBS and CTS synergistically can remove cyanide compound in liquid medium at maximum temperature condition $35^{\circ} \mathrm{C}$ and contact time 36 hours. Further research is needed to identify mixed culture of TBS and CTS.

\section{References}

1. Hidayati, N., Mercury and Cyanide Contaminations in Gold Mine Environment and Possible Solution of Cleaning Up by Using Phytoextraction. Journal of Biosciences. J of Biosciences. 16(3):88-94. (2009)

2. Luque-Almagro, V, M., Biodegradation of Cyanide Wastes from Mining and Jewellery Industries. 38:913. (2016)

3. Mekuto, L., Biodegradarion of Free Cyanide Using Bacillus Sp. Consortium Dominated by Bacillus Safensis, Lichenformis and Tequilensis Strains. A Bioprocess Supported Solely with Whey. S18:004. (2013)

4. Deloya, A. Treatment of Cyanide Wastes Through Bioremediation. Teknologi Maret. English Special Edition. 25(2):81-72. (2016)

5. Parmar, P., Isolation and Characterization of Cyanide Degrading Bacterial Strains from Contaminated Soil. Int. J of Environmental Sciences. 2(4):2006-2014. (2012) 
6. Naveen, D. Biological Treatment of Cyanide Containing Wastewater. Research Journal of Chemical Sciences. 1(7):15-21. (2011)

7. Razanamahandry, L, C., Biodegradation of Free Cyanide by Bacterial Species Isolated from Cyanide-Contaminated Artianal Gold Mining Catchment Area in Burkina Faso. Chemosphere. 157:71-78. (2016)

8. Maniyam, M, N., Biodegradation of Cyanide by Rhodococcus Strains Isolated in Malaysia. International Conference on Food Engineering and Biotechnology. 9:21-25. (2011)

9. Akinpelu, E, A., Biodegradation Kinetics of Free Cyanide in Fusarium oxysporum-Beta vulgaris Waste-metal (As, $\mathrm{Cu}, \mathrm{Fe}, \mathrm{Pb}, \mathrm{Zn}$ ) Cultures under Alkanline Conditions. Bioresources. 11 (1): 24702482. (2016)

10. Santos, B, A, Q. Application of Citrus sinensis Solid Waste as A Pseudo-Catalyst for Free Cyanide Conversion Under Alkaline Conditions. Bioresources. 8(3):3461-3467. (2013)

11. Maniyam, M, N., Biodegradation of cyanide by Rhodococcus UKMP-5M. Section Cellular and Molecular Biology. 68 (2):177-185. (2013)

12. Kumar, R., Remediation of Cyanide-Contaminated Environments Through Microbes and Plants. International Biodeterioration and Biodegradation. 99:123-128. (2016)

13. Fraga, E, G., Antimicrobial Susceptibility od Brazilian Clostridium difficile Strains Determined by Agar Dilution and Disk Diffusion. The Brazilian J of Infectious Diseases. 20(5):476-481 (2016)

14. Khamar, Z., Remediation of Cyanide from The Gold Mine Tailing Pond by A Novel Bacterial Co-culture. $\mathrm{J}$ Int Biodeterioration and Biodegradation. 99:123128. (2015)

15. Sankaranarayanan, A., Gowthami, M. Cyanide Degradation by Consortium of Bacterial Species Isolated from Sago Industry Effluent. $\mathrm{J}$ of Environmental Treatment Techniques. 3(1):41-46. (2015) 